\title{
The layered structure model for winonaite parent asteroid implicated by textural and mineralogical diversity
}

Xiaojia Zeng ${ }^{1,3,4}$, Yingli Shang ${ }^{1}$, Shijie $\mathrm{Li}^{1,2^{*}}$, Xiongyao $\mathrm{Li}^{1,2,3}$, Shijie Wang ${ }^{5}$ and Yang $\mathrm{Li}^{1,2,3}$

\begin{abstract}
The winonaites are primitive achondrites that are associated with IAB iron meteorites. They provide valuable insights into differentiation processes on asteroids in the early Solar System. However, there is still little understanding of the lithological diversity as well as the structure of the winonaite parent asteroid. In this work, we report the petrologic texture and mineralogy of a suite of winonaites (i.e., Northwest Africa (NWA) 725, NWA 6448, NWA 4024, Grove Mountains (GRV) 022890, GRV 021663, and Sahara (SAH) 02029) that exhibit a wide diversity of petrographic textures from primitive chondritic texture to coarse-grained equigranular texture. In particular, we recognized an unusual winonaite (SAH 02029) with a distinctive mineralogy and mineral chemistry (e.g., depleted in troilite, plagioclase contains melt inclusions, high plagioclase An values, and LREE-depleted clinopyroxene). The petrological and mineralogical features of SAH 02029 indicate that this meteorite has undergone silicate partial melting and may represent the residue of $\sim 5-10$ vol\% partial melting. The textural and mineralogical diversity among winonaites suggests that the winonaiteIAB parent asteroid would have formed a four-layered structure during its evolution history: (1) surface layer consisting of precursor chondritic materials; (2) subsurface layer composed of diverse lithologies that experienced limited metamorphism and FeNi-FeS partial melting; (3) deep residues of silicate partial melting; and (4) interior layer consisting of incomplete differentiation metal pools. This conclusion enables us to establish constraints on the evolution history of winonaite-IAB parent body.
\end{abstract}

Keywords: Primitive achondrite, Winonaite, Partial melting, Structure of asteroid

\section{Introduction}

The primitive achondrites (e.g., acapulcoites, lodranites, brachinites, and winonaites) can provide a glimpse into the early differentiation and initial partial melting processes of chondritic planetesimals in the early Solar System (e.g., Prinz et al. 1980; McCoy et al. 1996; Benedix et al. 1998; Goodrich et al. 2011). The winonaite group is discriminated from all of other primitive achondrite groups based on its mineralogy, mineral composition, and importantly the oxygen isotopic composition (Graham et al. 1977; Prinz et al. 1980; Kimura and Tsuchiyama 1992; Clayton and Mayeda 1996). To date, only 33

\footnotetext{
*Correspondence: lishijielpsc@mail.gyig.ac.cn

${ }^{1}$ Center for Lunar and Planetary Sciences, Institute of Geochemistry,

Chinese Academy of Sciences, Guiyang 550081, China

Full list of author information is available at the end of the article
}

meteorites have been classified as winonaites (Meteoritical Bulletin Database, accessed 12/02/2019). In terms of the small number of members of this group, there is much left to understand about the lithological diversity of winonaites (especially for the non-well-studied winonaite samples; Benedix et al. 1998; Hunt et al. 2017).

The winonaites are characterized as they are highly heterogeneous in grain size, petrologic texture, and modal mineralogy (e.g., Benedix et al. 1998; Floss et al. 2007; Li et al. 2011; Hunt et al. 2017). Such diverse lithologies suggest that complex and varied processes have acted on the winonaite parent asteroid (Benedix et al. 1998; Floss et al. 2007). However, investigations on the textural and mineralogical variation of winonaite achondrites are limited and only about a dozen samples have been studied in detail (e.g., Graham et al. 1977; Prinz et al. 1980; King et al. 1981; Kimura and Tsuchiyama 1992; Benedix et al. 
1998; Floss et al. 2007; Li et al. 2011; Hunt et al. 2017). Previous studies revealed that the winonaites experienced extensive thermal metamorphism, resulting in the limited FeNi-FeS partial melting and possible silicate partial melting (Benedix et al. 1998; Floss et al. 2008; Li et al. 2011; Hunt et al. 2017). While few samples have been recognized as residues of silicate partial melting, only one winonaite (i.e., Tierra Blanca) was interpreted as a residue of small-degree silicate melting from the geochemical evidences (Hunt et al. 2017).

Previous studies have shown that winonaites derive from the same body with silicate inclusions in IAB irons. This is evidenced by their similarities in mineralogy, oxygen isotopic compositions, and Mo isotopic compositions (Clayton and Mayeda 1996; Benedix et al. 1998, 2000; Worsham et al. 2017). To date, the most prevalent model suggested that the winonaite-IAB parent body has undergone incomplete differentiation, followed by catastrophic impact breakup and reassembly (Benedix et al. 2000). This impact would terminate further magmatic evolution and enable the winonaites to preserve the type of differentiation processes that occurred on small asteroids in early Solar System (e.g., Hunt et al. 2017). To constrain the history of winonaite-IAB parent body, we present textural and mineralogical variations of a suite of nonwell-examined winonaites, including Northwest Africa (NWA) 725, NWA 6448, NWA 4024, Grove Mountains (GRV) 022890, GRV 021663, and Sahara (SAH) 02029. This study aims to (1) characterize these non-well-studied winonaites; (2) investigate the lithological diversity of winonaites; and (3) discuss the layered structure model for winonaite-IAB parent asteroid recorded by the textural and mineralogical diversity of winonaites.

\section{Samples and methods}

Four polished thick sections (i.e., NWA 725, NWA 6448, NWA 4024, and SAH 02029) were made at Institute of Geochemistry, Chinese Academy of Sciences (IGCAS). We also acquired two polished thin sections (GRV 021663 and GRV 022890) from the Polar Research Institute of China (PRIC) for investigation. These sections (Additional file 1: Fig. A1) were coated with carbon and investigated using different in situ analytical techniques.

Backscattered electron (BSE) images were collected by using a FEI Scios dual-beam focused ion beam/scanning electron microscope (FIB/SEM) at IGCAS. The operation conditions were $15-20 \mathrm{kV}$ accelerating voltage, 3.2-6.8 $\mathrm{nA}$ beam current, and 7-9 $\mathrm{mm}$ working distance. The mineral distribution maps (Additional file 1: Figs. A2-7) of the studied sections were made from X-ray element mapping with energy-dispersive spectrometer (EDS) attached on the same FEI Scios FIB/SEM. The conditions for X-ray mapping were as follows: $25 \mathrm{kV}$ accelerating voltage, $3.2 \mathrm{nA}$ beam current, and $10 \mathrm{~mm}$ working distance. Nine mineral phases (i.e., olivine, orthopyroxene, clinopyroxene, plagioclase, FeNi metal, troilite, chromite, phosphate, and $\mathrm{Fe}$-oxides) were distinguished by the distribution of elements (e.g., $\mathrm{Si}, \mathrm{Al}, \mathrm{Ca}, \mathrm{Mg}, \mathrm{Na}, \mathrm{K}, \mathrm{S}, \mathrm{Fe}, \mathrm{P}$, $\mathrm{O}, \mathrm{F}, \mathrm{Cl}, \mathrm{Ti}, \mathrm{Cr}$, and $\mathrm{Ni}$ ). The modal abundances for the studied samples were determined using 6-8 mineral distribution maps, with the total areas of $\sim 48-64 \mathrm{~mm}^{2}$. An average modal abundance (Table 1) was then calculated from these data, and the standard deviation was generally less than $2 \%$.

The major elements of silicate minerals (i.e., orthopyroxene, clinopyroxene, olivine, and plagioclase) were determined using a JEOL JXA-8230 electron microprobe analysis (EMPA) in Guilin University of Technology. The operating conditions were as follows: a $15 \mathrm{kV}$ accelerating voltage, a $20 \mathrm{nA}$ beam current, and a focused beam of 1-2 $\mu \mathrm{m}$ diameter (Zeng et al. 2018). Natural minerals and synthetic minerals were used as standards. A ZAF correction was applied to all EMPA data. Detection limits are typically $0.01-0.02 \mathrm{wt} \%$ for $\mathrm{Na}_{2} \mathrm{O}, \mathrm{MgO}, \mathrm{Al}_{2} \mathrm{O}_{3}, \mathrm{~K}_{2} \mathrm{O}$, and $\mathrm{CaO} ; 0.03 \mathrm{wt} \%$ for $\mathrm{FeO}$ and $\mathrm{TiO}_{2}$; and $0.05 \mathrm{wt} \%$ for $\mathrm{SiO}_{2}, \mathrm{MnO}$, and $\mathrm{Cr}_{2} \mathrm{O}_{3}$.

The rare earth elements (REE) in silicate minerals (i.e., clinopyroxene, orthopyroxene, and plagioclase) were obtained directly from polished sections using a laser ablation inductively coupled plasma mass spectrometry (LA-ICPMS) without applying an internal standard at IGCAS. Detailed analytical procedures follow those described by Liu et al. (2008). Laser analysis was performed using a GeoLasPro 192-nm laser ablation system. The laser was operated at $8 \mathrm{~Hz}$ with a fluence of $14 \mathrm{~J} /$ $\mathrm{cm}^{2}$. Ion signal intensities were acquired using an Agilent 7700x ICPMS instrument with helium as the carrier gas. The ICPMS system was operated under standard conditions at $1350 \mathrm{~W}$ and optimized for low oxide formation (typically $\mathrm{ThO} / \mathrm{Th}<0.3 \%$ ). The diameter of the laser spot was $32 \mu \mathrm{m}$. Each analysis consisted of approximately 10-s background measurement (laser-off) followed by 50 -s data acquisition. The United States Geological Survey (USGS) standard reference material NIST SRM 610 was used to correct for instrumental fractionation and drift. The USGS reference glasses BIR-1G were used to monitor external reproducibility. Data reduction was performed using ICPMSDataCal software (Liu et al. 2008, 2010).

\section{Results}

\section{Petrographic texture}

The studied six winonaites (i.e., NWA 725, NWA 6448, GRV 022890, GRV 021663, NWA 4024, and SAH 02029) exhibit a wide diversity of petrographic textures ranging from a chondritic texture, to fine- and coarse-grained 
Table 1 Modal abundance of minerals in winonaites (by area, vol\%)

\begin{tabular}{|c|c|c|c|c|c|c|c|c|c|c|c|c|}
\hline Samples & Opx & Ol & $\mathrm{PI}$ & Cpx & Php & Tro & Chr & Metal $^{a}$ & Other $^{b}$ & Silicate & Opaque & References \\
\hline NWA 725 & 40.3 & 11.8 & 10.1 & 5.0 & 0.7 & 10.3 & 0.9 & 21.0 & - & 67.9 & 32.2 & This work \\
\hline NWA 6448 & 53.8 & 19.7 & 11.5 & 2.3 & 1.0 & 3.5 & 0.2 & 8.0 & - & 88.3 & 11.7 & This work \\
\hline GRV 022890 & 39.4 & 23.0 & 15.4 & 6.8 & - & 6.4 & 1.0 & 8.1 & $\operatorname{tr}$ & 84.6 & 15.5 & This work \\
\hline GRV 021663 & 27.5 & 49.5 & 1.7 & 5.7 & $\operatorname{tr}$ & 4.5 & 0.5 & 10.7 & - & 84.3 & 15.7 & This work \\
\hline NWA 4024 & 7.5 & 3.7 & 4.2 & 1.3 & 1.0 & 1.8 & - & 80.5 & - & 16.7 & 82.3 & This work \\
\hline SAH 02029 & 37.8 & 34.6 & 6.4 & 3.5 & - & 2.3 & 0.0 & 15.4 & 0.0 & 82.3 & 17.7 & This work \\
\hline NWA 8614 & 44.3 & 12.3 & 10.1 & 4.6 & 0.7 & 6.9 & 0.4 & 20.4 & 0.4 & 71.3 & 27.7 & Farley et al. (2015) \\
\hline NWA 1463 & 48.8 & 10.4 & 6.4 & 8.7 & 0.4 & 8.8 & 0.3 & 16 & 0.1 & 74.3 & 25.1 & Hunt et al. (2017) \\
\hline Pontlyfni & 33.4 & 13.7 & 14.2 & 3.1 & - & 21.0 & - & 12.9 & 2.1 & 64.4 & 33.9 & Hunt et al. (2017) \\
\hline Fortuna & 39.1 & 24.7 & 16.3 & 4.6 & 0.3 & 7.1 & 0.2 & 7.67 & - & 84.7 & 15.0 & Hunt et al. (2017) \\
\hline Winona & 32.4 & 16.7 & 19.5 & 2.2 & 0.4 & 5.8 & 0.1 & 28.7 & $\operatorname{tr}$ & 70.8 & 34.6 & Hunt et al. (2017) \\
\hline Mt. Morris & 30.1 & 10 & 15.5 & 0.2 & - & 5.2 & $\operatorname{tr}$ & 38.2 & 0.7 & 55.8 & 43.4 & Hunt et al. (2017) \\
\hline $\mathrm{HaH} 193$ & 36.1 & 17 & 13.6 & 1.9 & 0.1 & 3.1 & $\operatorname{tr}$ & 26.6 & 1.6 & 68.6 & 29.7 & Hunt et al. (2017) \\
\hline GRV $021663^{c}$ & 17 & 56 & 1.4 & 8 & 0 & - & - & - & - & 82.4 & 17.0 & Li et al. (2011) \\
\hline Tierra Blanca & 32.7 & 27.6 & 10.2 & 0.2 & 0.1 & 3.8 & 0.0 & 25.5 & 0.0 & 70.7 & 29.3 & Yugami et al. (1998) \\
\hline Y-75300 & 51.2 & 16.6 & 10.3 & 0.0 & - & 18.8 & - & 2.3 & 1.0 & 78.1 & 21.1 & Kimura and Tsuchiyama (1992) \\
\hline$Y-74025$ & 45.6 & 19.9 & 8.3 & 7.2 & - & 13.5 & - & 3.9 & 1.6 & 81.0 & 17.4 & Kimura and Tsuchiyama (1992) \\
\hline Y-75305 & 45.0 & 7.8 & 8.3 & 1.2 & - & 9.2 & 0.2 & 27.0 & 1.3 & 62.3 & 36.4 & Kimura and Tsuchiyama (1992) \\
\hline Y-8005 & 28.4 & 11.8 & 13.5 & 6.2 & 0.0 & 7.2 & 0.0 & 31.7 & 1.1 & 59.9 & 38.9 & Yugami et al. (1998) \\
\hline NWA 1058 & 18.8 & 33.8 & 9.6 & 6.4 & 1.2 & 7.0 & 0.4 & 20.1 & - & 68.6 & 27.5 & Cecchi and Caporali (2015) \\
\hline QUE 94535 & 41.3 & 24 & 14.8 & 2.9 & - & 6.6 & $\operatorname{tr}$ & 9.76 & 0.7 & 83.0 & 16.4 & Hunt et al. (2017) \\
\hline
\end{tabular}

Opx orthopyroxene, Ol olivine, PI plagioclase, Cpx clinopyroxene, Php phosphate, Tro troilite, Chr chromite, tr trac, "-" not analyzed or not detected

a Metal includes Fe-rich weathering products produced from both metal and/or troilite

b Other includes the accessory minerals (e.g., schreibersite, daubreelite, amphibole, alabandite, and graph)

c This modal mineralogy was estimated using BSE images and X-ray element maps. Different analysis areas could affect the estimate results

equigranular textures (Fig. 1 and Additional file 1: Figs. A2-7). The petrologic textures of each meteorite were described below in approximate order of increasing grain size and degree of metamorphism.

\section{Primitive winonaite NWA 725}

NWA 725 was originally classified as an acapulcoitelodranite achondrite (Grossman and Zipfel 2001). While it has since been reclassified as a member of the winonaite group based on its oxygen isotope composition (Greenwood et al. 2012), this meteorite displays a chondritic texture which is similar to that of a type 6 chondrite (Fig. 2a-c and Additional file 1: Fig. A2). About 5 vol\% relict chondrules (e.g., porphyritic olivine-pyroxene chondrule; Fig. 2c) have been observed in this section. The FeNi metal and troilite grains $(<50-1000 \mu \mathrm{m})$ are scattered through the studied section (Fig. 2a). Using Adobe Photoshop software to analyze BSE images, it can be estimated that NWA 725 has $~ 10 \%$ porosity, mainly distributed between mineral grains and borders of chondrules and matrix (e.g., Fig. 2b, c). These estimated data (i.e., $\sim 10 \%$ ) are similar to the measured porosity for NWA 725 (i.e., $12.35 \pm 2.19 \%$; Macke et al. 2011).

2. Diverse lithologies experienced limited metamorphism and partial melting (NWA 6448, GRV 022890, GRV 021663, and NWA 4024)

NWA 6448 is a fine-grained ( $90 \mu \mathrm{m}$ in size) winonaite, which is similar to the texture of a type 6 chondrite (Fig. 2d, e). In contrast, GRV 022890 exhibits medium-grained $(\sim 120 \mu \mathrm{m}$ in size $)$ recrystallized texture (Fig. 2f, g). Plagioclase grains in this meteorite are interconnected in a complex network at millimeter scales (Fig. 2f) and always associated with clinopyroxenes, implying that these minerals are crystallized from a basaltic partial melt (e.g., Izawa et al. 2011). Two euhedral clinopyroxene crystals were observed to be enclosed by plagioclase (Fig. 2h), which is also suggestive of a basaltic melt crystallization. GRV 021663 is a coarse-grained $(\sim 200-250 \mu \mathrm{m})$ olivine-rich winonaite and shows equigranular texture with abundant of $120^{\circ}$ triple junctions (Fig. 2i, j; Li et al. 2011). This meteorite consists predominantly of olivine grains of 

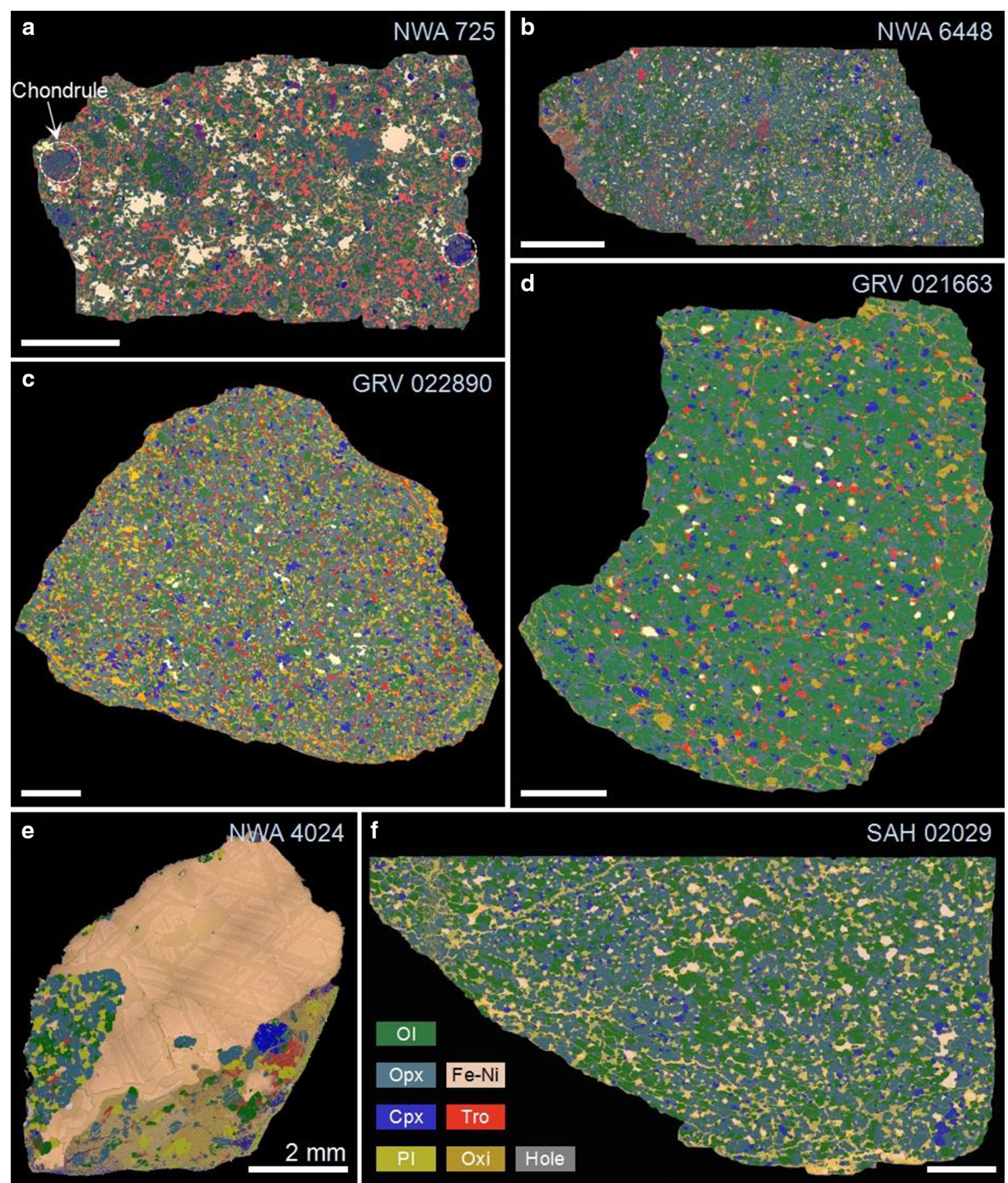

Fig. 1 Mineral distribution maps for the studied winonaites. The meteorites show a wide variety of petrographic textures, including chondritic texture (a), fine-grained texture (b), recrystallized texture (c), olivine-rich texture (d), metal-rich texture (e), and troilite-poor texture (f). Scale bar in all images is $2 \mathrm{~mm}$. The minerals displayed include olivine (Ol), orthopyroxene (Opx), clinopyroxene (Cpx), plagioclase (PI), FeNi metal (Fe-Ni), troilite (Tro), and Fe-Fe-oxides (Oxi)

49.5 vol\%, with less amount of plagioclase (1.7 vol\%; Table 1). For the studied NWA $4024(\sim 7 \times 9 \mathrm{~mm})$, this meteorite displays coarse-grained metal-rich texture (Fig. 1e). The silicate lithology of NWA 4024 is relatively coarse-grained $(\sim 200-250 \mu \mathrm{m})$, displays irregular or sub-rounded shapes (Fig. 2k, l), and exhibits an equilibrium texture that is similar to Winona (Benedix et al. 1998). While the FeNi metal region of NWA 4024 shows the Widmanstätten pattern of the IAB iron meteorites (Fig. 1e; Benedix et al. 2000). 

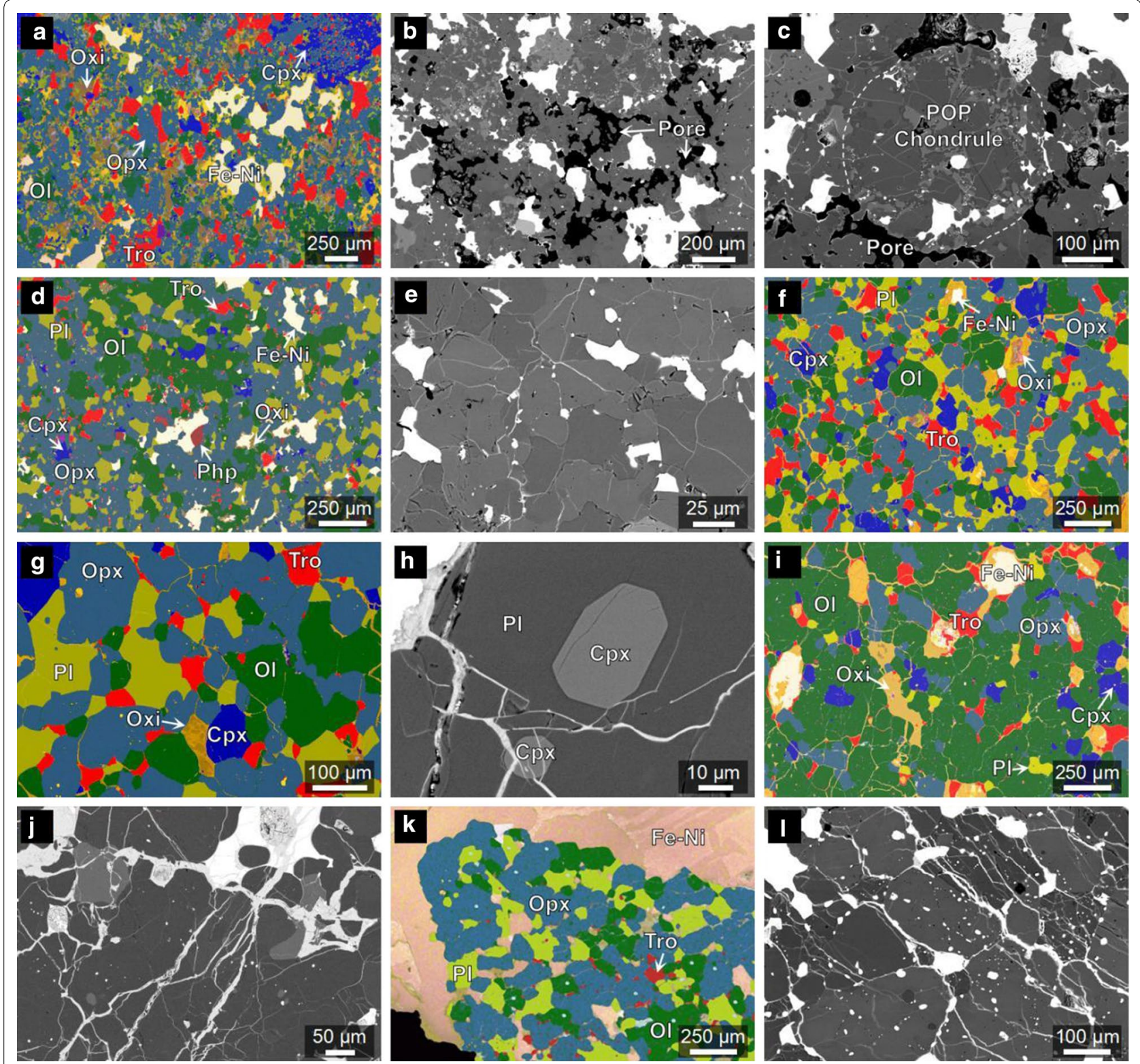

Fig. 2 Petrologic textures of the studied winonaites. a-c Representative areas of NWA 725 with relict chondrules (e.g., Figure 2c). d, e The representative areas of NWA 6448 with fine-grained texture. $\mathbf{f}, \mathbf{g}$ Representative area of GRV 022890 with medium-grained equigranular texture. h Two euhedral clinopyroxene crystals are enclosed by plagioclase in GRV 022890. $\mathbf{i}$, j Representative areas of GRV 021663 with coarse-grained olivine-rich texture and metal veinlets. k Representative area of NWA 4024 with the coarse-grained metal-rich texture. I Curvilinear trails of metallic FeNi blebs (white) in mafic silicate grains of NWA 4024. The labeled minerals include olivine (Ol), orthopyroxene (Opx), clinopyroxene (Cpx), plagioclase (PI), FeNi metal (Fe-Ni), troilite (Tro), and Fe-oxides (Oxi). POP porphyritic olivine-pyroxene chondrule

All these samples experienced relatively high-grade metamorphism and reached the FeNi-FeS cotectic melting point. Veins of FeNi metal-troilite are pervasively common in these sections, crosscutting the silicate grains and silicate-silicate boundaries forming an interlock network of metal/troilite veins.

3. Coarse-grained troilite-poor winonaite SAH 02029
The most distinctive feature of SAH 02029 is that it is a coarse-grained $(\sim 250-300 \mu \mathrm{m})$ troilite-poor $(2.3 \mathrm{vol} \%)$ winonaite (Fig. 3a; Table 1). It has equigranular silicate grains with abundant $120^{\circ}$ triple junctions that reflect the extensive solid-state recrystallization (Fig. 3a, b). Most olivine grain boundaries are generally rounded, with various grain sizes of $\sim 200-400 \mu \mathrm{m}$ (Fig. 3a). The clinopyroxene and plagioclase are irregular in shape and 


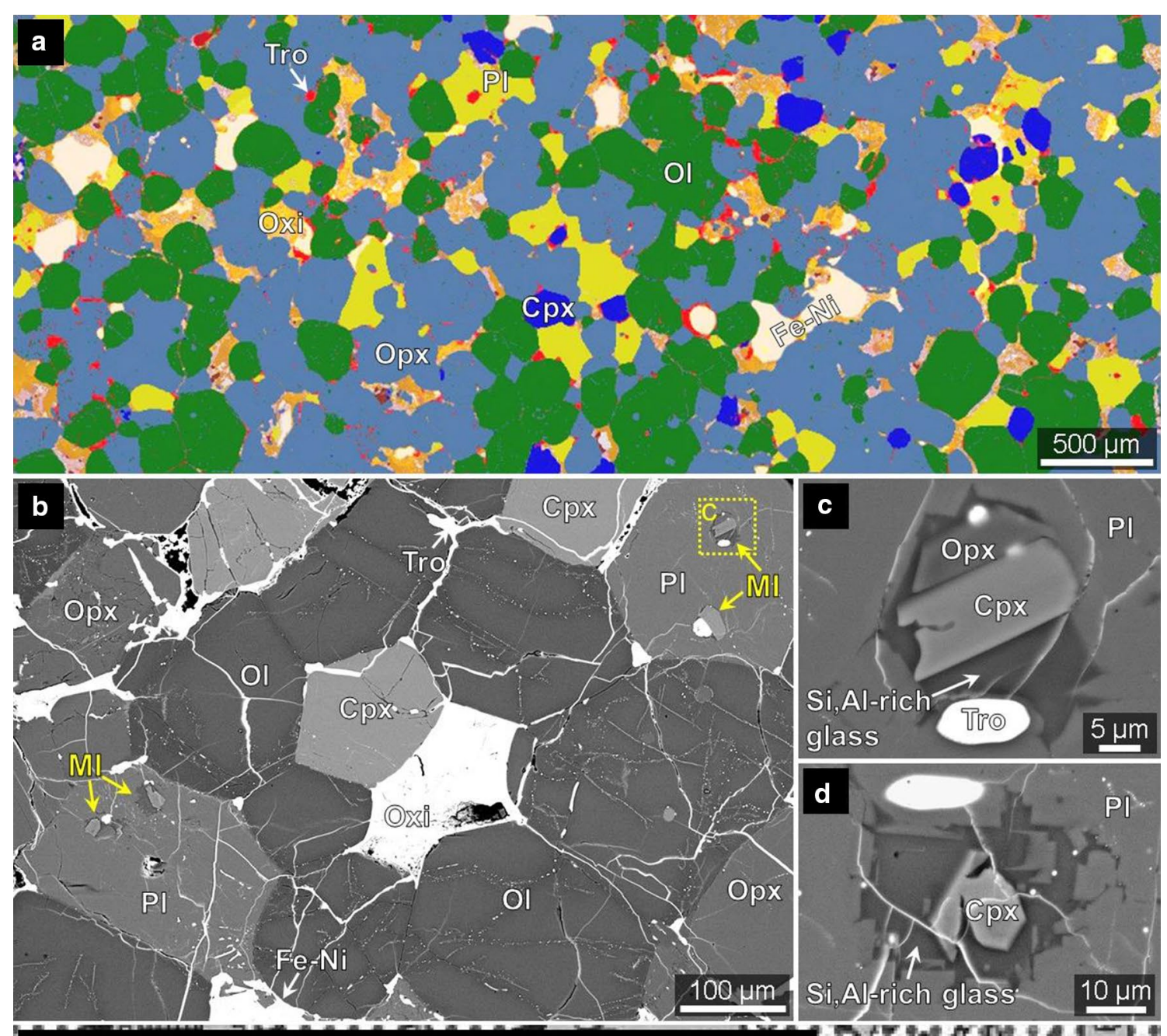

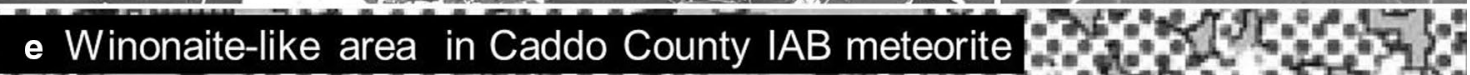

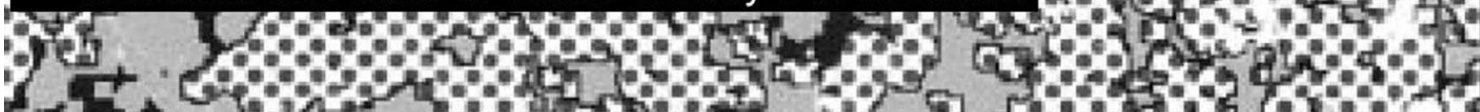

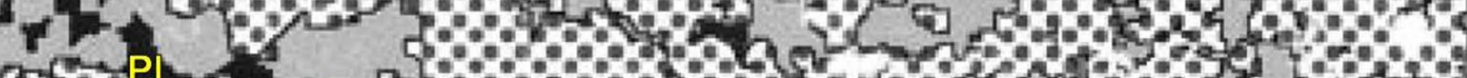

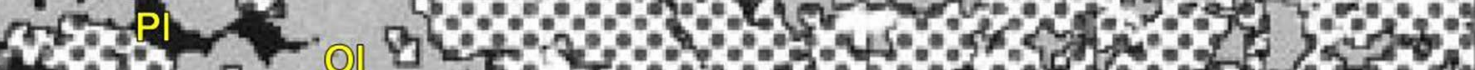

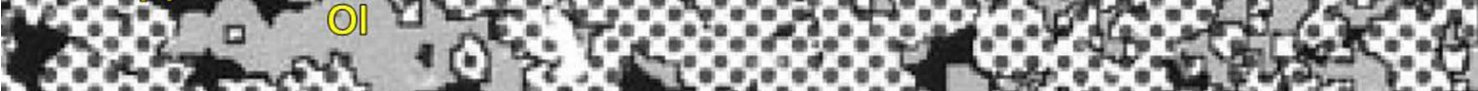

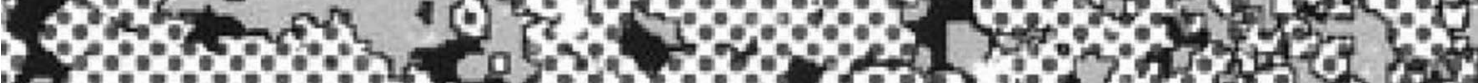

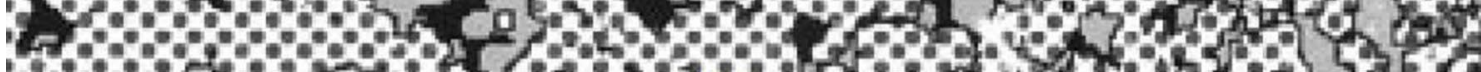

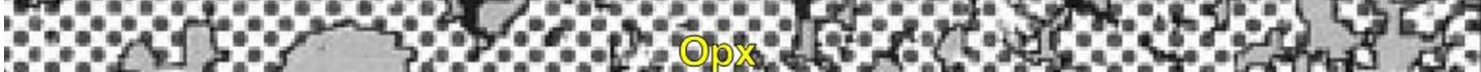

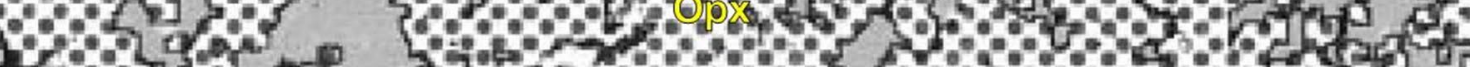

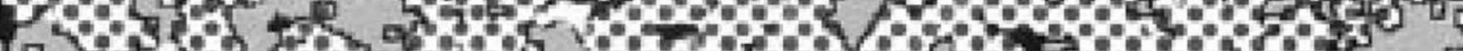

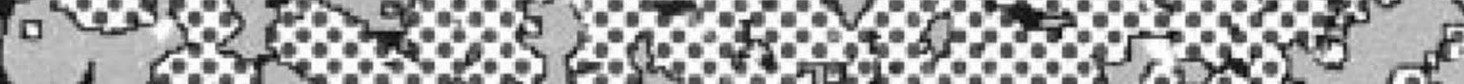

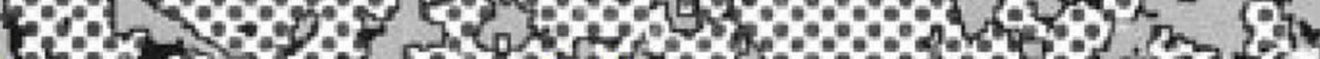

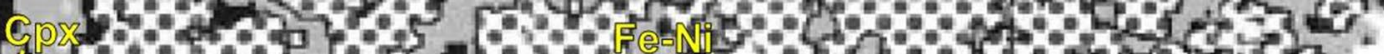

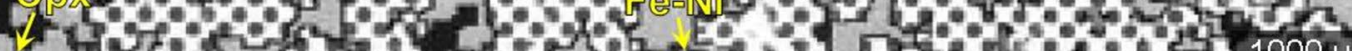

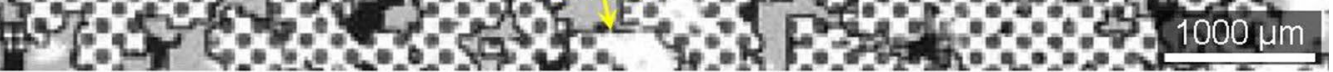

Fig. 3 Petrologic textures of the SAH 02029 winonaite. a Representative area of SAH 02029 with coarse-grained equigranular texture. b-d BSE image of the representative area of SAH 02029. Multiple melt inclusions (MI) were observed in the plagioclase crystals (c, d). e Mineral distribution map of winonaite-like area in Caddo County IAB meteorite (Takeda et al. 2000). The labeled minerals include olivine (OI), orthopyroxene (Opx), clinopyroxene (Cpx), plagioclase (PI), FeNi metal (Fe-Ni), troilite (Tro), and Fe-oxides (Oxi) 
heterogeneously distributed, with the grain size ranging from $<50$ up to $\sim 800 \mu \mathrm{m}$ (Figs. 3a, 1f). In most case, both of them are associated with each other (Fig. 3a). In addition, melt inclusions $(\sim 20-40 \mu \mathrm{m}$ in size) were observed in plagioclases of SAH 02029 (e.g., Fig. 3c, d). They are irregular in shape and mainly consist of euhedral clinopyroxene (augite), orthopyroxene, Si-, Al-rich glass, as well as tiny metal/sulfide grains (Fig. 3c, d). Such Si-, Alrich glasses are mainly composed of $\mathrm{SiO}_{2}(\sim 75 \mathrm{wt} \%)$ and $\mathrm{Al}_{2} \mathrm{O}_{3}(\sim 15 \mathrm{wt} \%)$.

Textually and mineralogically, the SAH 02029 is similar to the reported coarse-grained winonaite Tierra Blanca (Fig. 2g of Benedix et al. 1998) and also the winonaitelike area in Caddo County IAB meteorite (Fig. 3e; Takeda et al. 2000). These lithologies show a recrystallized texture and are mostly composed of orthopyroxene and olivine (Benedix et al. 1998; Takeda et al. 2000).

In the studied section of SAH 02029, FeNi metal grain forms large isolated grains (up to $\sim 800 \mu \mathrm{m}$ ) or fills the cracks of silicate phases and crosscutting the studied section (Fig. 1f). Approximately $50 \mathrm{vol} \%$ of Fe-Ni metal grains have been replaced by weathering products (e.g., Fe-oxide/oxy-hydroxide; Lee and Bland 2004), which is consistent with a weathering grade W2 (Wlotzka 1993). Although some troilite grains in this meteorite were observed associated with weathering products, the troilite grains between/within silicate grains do not show weathering texture (Fig. 3a). This suggests that only a few troilite in SAH 20209 have been alternated by the terrestrial weathering process.

\section{Modal mineralogy}

The studied six winonaites show extremely variable modal abundance of both silicates and opaque phases (Table 1 and Fig. 4). Specifically, the volume percentage of olivine varies from $3.7 \mathrm{vol} \%$ (NWA 4024) to $49.5 \mathrm{vol} \%$ (GRV 021663). The abundance of orthopyroxene varies widely from $7.5 \mathrm{vol} \%$ (NWA 4024) to $53.8 \mathrm{vol} \%$ (NWA 6448). The plagioclase contents vary from $1.7 \mathrm{vol} \%$ in GRV 021663 to $15.4 \mathrm{vol} \%$ in GRV 022890. In addition, the opaque phases in the studied meteorites also vary dramatically in modal abundance (Table 1 and Fig. 4). FeNi metal contents in the studied samples vary from $8.0 \mathrm{vol} \%$ (NWA 6448) to 80.5 vol\% (NWA 4024), and the troilite contents vary from $1.8 \mathrm{vol} \%$ in NWA 4024 to $10.3 \mathrm{vol} \%$ in NWA 725, although terrestrial weathering could increase the uncertainties for estimating the FeNi metal and troilite abundance.

\section{Mineral chemistry}

Each studied winonaite has relatively homogeneous mineral compositions across this section (Table 2). The olivine fayalite $\left(\mathrm{Fa}_{2.7-6.6}\right)$ and orthopyroxene ferrosilite $\left(\mathrm{Fs}_{2.7-7.9}\right)$

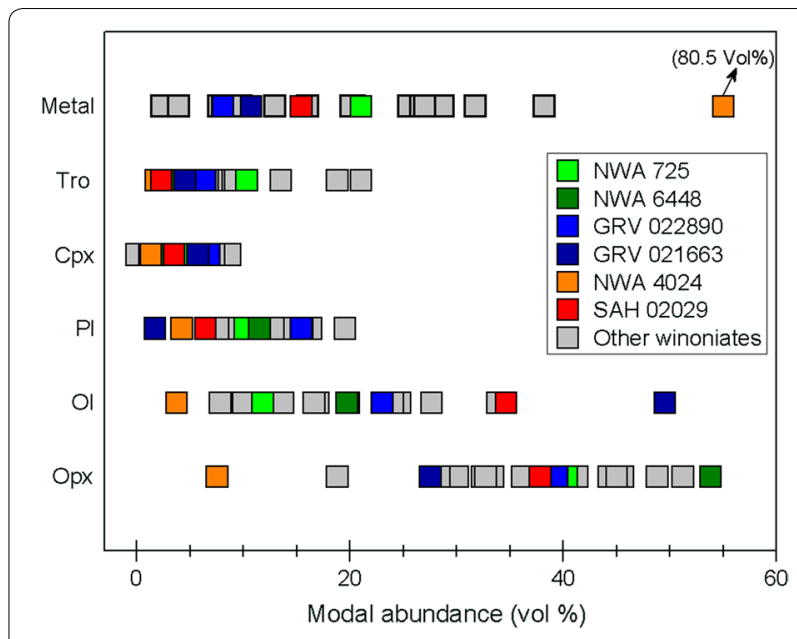

Fig. 4 Modal abundance (by area \%) variation of the major phases in the winonaites (Table 1). They are orthopyroxene (Opx), olivine $(\mathrm{Ol})$, plagioclase (PI), clinopyroxene (Cpx), troilite (Tro), and metal (including the Fe-rich weathering products produced from metal and troilite). The color symbols represent the studied winonaite samples. The light gray symbols represent the reported data for other winonaites (see Table 1)

contents of these meteorites are similar to the mineral composition for other reported winonaites (Fig. 5a). Likewise, both orthopyroxene $\left(\mathrm{En}_{90.6-94.6} \mathrm{Fs}_{2.7-7.9} \mathrm{Wo}_{1.3-4.2}\right)$ and clinopyroxene $\left(\mathrm{En}_{50.1-56.0} \mathrm{Fs}_{1.8-3.4} \mathrm{Wo}_{42.2-46.5}\right)$ grains in the studied winonaites also exhibit a narrow composition variation, which overlap the composition range of other winonaites (Fig. 5b). However, the plagioclase grains in the studied samples show a relatively large composition variation; most winonaites contain plagioclase with low An $(=$ molar $100 \times \mathrm{Ca} /$ $[\mathrm{Ca}+\mathrm{Na}+\mathrm{K}]$ ) values of $5.1-21.5$, while SAH 02029 shows distinctive plagioclase An value of 52.0 (Fig. 5c).

\section{Rare earth elements in silicates}

The rare earth element (REE) abundance for silicate minerals (i.e., orthopyroxene, clinopyroxene, and plagioclase; Additional file 1: Table A1) within the studied winonaites was measured for comparison with that in other winonaites (Floss et al. 2008; Li et al. 2011). For orthopyroxene, the REE patterns and compositional ranges of the studied winonaites are generally similar to those of other reported winonaites (Fig. 6a). They exhibit heavy rare earth element (HREE)-enriched patterns with La at $\sim 0.02-0.3 \times \mathrm{CI}$ and $\mathrm{Lu}$ at $0.3-1 \times \mathrm{CI}$, showing negative Eu-anomalies (Fig. 6a).

Clinopyroxene grains in five winonaites (i.e., NWA 725, NWA 6448, NWA 4024, GRV 022890, and GRV 021663) exhibit relatively flat patterns $(\mathrm{La} \sim 9-11 \times \mathrm{CI}$, $\mathrm{Lu} \sim 8-11 \times \mathrm{CI}$ ) with negative Eu-anomalies (Fig. 6b). Their REE abundances and patterns are similar to those of clinopyroxenes for other reported winonaites in Floss 
Table 2 Average major composition of olivine (OI), orthopyroxene (Opx), clinopyroxene (Cpx), and plagioclase (PI) in the studied winonaites (wt\%)

\begin{tabular}{|c|c|c|c|c|c|c|c|c|}
\hline & \multicolumn{4}{|l|}{ NWA 725} & \multicolumn{4}{|l|}{ NWA 6448} \\
\hline & Ol & Opx & $C p x$ & PI & Ol & Opx & Cpx & PI \\
\hline $\mathrm{SiO}_{2}$ & $41.6 \pm 0.69$ & $58.6 \pm 0.84$ & $55.5 \pm 0.84$ & $64.6 \pm 1.80$ & $41.9 \pm 0.93$ & $57.7 \pm 0.65$ & $54.4 \pm 0.87$ & $64.2 \pm 1.10$ \\
\hline $\mathrm{TiO}_{2}$ & b.d. & $0.16 \pm 0.04$ & $0.58 \pm 0.08$ & $0.06 \pm 0.05$ & b.d. & $0.22 \pm 0.10$ & $0.65 \pm 0.08$ & $0.05 \pm 0.06$ \\
\hline $\mathrm{Al}_{2} \mathrm{O}_{3}$ & b.d. & $0.21 \pm 0.08$ & $0.69 \pm 0.11$ & $22.1 \pm 0.56$ & b.d. & $0.23 \pm 0.09$ & $0.74 \pm 0.11$ & $21.8 \pm 0.79$ \\
\hline $\mathrm{Cr}_{2} \mathrm{O}_{3}$ & b.d. & $0.20 \pm 0.05$ & $1.02 \pm 0.15$ & $0.10 \pm 0.56$ & b.d. & $0.31 \pm 0.18$ & $1.03 \pm 0.20$ & b.d. \\
\hline $\mathrm{FeO}$ & $6.44 \pm 0.87$ & $5.35 \pm 0.36$ & $2.11 \pm 0.39$ & $0.49 \pm 0.40$ & $4.62 \pm 0.41$ & $4.27 \pm 0.27$ & $2.08 \pm 0.82$ & $0.28 \pm 0.35$ \\
\hline $\mathrm{MnO}$ & $0.48 \pm 0.10$ & $0.58 \pm 0.07$ & b.d. & b.d. & $0.30 \pm 0.09$ & $0.47 \pm 0.22$ & b.d. & b.d. \\
\hline $\mathrm{MgO}$ & $51.2 \pm 0.61$ & $34.4 \pm 0.90$ & $17.4 \pm 0.63$ & $0.03 \pm 0.10$ & $52.9 \pm 1.46$ & $34.7 \pm 1.21$ & $17.4 \pm 1.03$ & b.d. \\
\hline $\mathrm{CaO}$ & $0.03 \pm 0.03$ & $0.78 \pm 0.25$ & $22.4 \pm 0.46$ & $2.51 \pm 0.22$ & $0.02 \pm 0.05$ & $0.67 \pm 0.25$ & $21.7 \pm 1.29$ & $2.97 \pm 0.18$ \\
\hline $\mathrm{Na}_{2} \mathrm{O}$ & b.d. & $0.02 \pm 0.03$ & $0.71 \pm 0.06$ & $9.23 \pm 0.55$ & b.d. & $0.03 \pm 0.04$ & $0.69 \pm 0.07$ & $9.02 \pm 0.60$ \\
\hline $\mathrm{K}_{2} \mathrm{O}$ & b.d. & b.d. & b.d. & $0.87 \pm 0.32$ & $0.03 \pm 0.08$ & $0.03 \pm 0.08$ & b.d. & $0.61 \pm 0.22$ \\
\hline Total & 99.85 & 100.30 & 100.4 & 100.0 & 99.80 & 98.68 & 98.7 & 99.00 \\
\hline Fo/En & 93.4 & 90.6 & 50.1 & & 95.3 & 92.3 & 51.0 & \\
\hline $\mathrm{Fa} / \mathrm{Fs}$ & 6.6 & 7.9 & 3.4 & & 4.7 & 6.4 & 3.4 & \\
\hline An & & & & 12.4 & & & & 14.9 \\
\hline$A b$ & & & & 82.5 & & & & 81.5 \\
\hline \multirow[t]{3}{*}{ No. } & 14 & 10 & 14 & 10 & 8 & 7 & 12 & 14 \\
\hline & \multicolumn{4}{|c|}{ GRV 022890} & \multicolumn{4}{|c|}{ GRV $021663^{a}$} \\
\hline & Ol & Opx & Cpx & PI & Ol & Opx & Cpx & PI \\
\hline $\mathrm{SiO}_{2}$ & $42.9 \pm 0.37$ & $56.7 \pm 8.56$ & $55.2 \pm 0.97$ & $64.5 \pm 0.70$ & 41.72 & 57.59 & 56.85 & 63.4 \\
\hline $\mathrm{TiO}_{2}$ & b.d. & $0.16 \pm 0.11$ & $0.69 \pm 0.09$ & $0.05 \pm 0.04$ & 0.03 & b.d. & 0.77 & 0.06 \\
\hline $\mathrm{Al}_{2} \mathrm{O}_{3}$ & b.d. & $0.23 \pm 0.14$ & $0.74 \pm 0.08$ & $22.6 \pm 0.53$ & 0.01 & 0.41 & 0.93 & 22 \\
\hline $\mathrm{Cr}_{2} \mathrm{O}_{3}$ & b.d. & $0.21 \pm 0.09$ & $0.61 \pm 0.13$ & b.d. & 0.47 & 0.9 & 1.5 & b.d. \\
\hline $\mathrm{FeO}$ & $2.72 \pm 0.15$ & $2.83 \pm 0.22$ & $1.17 \pm 0.35$ & $0.25 \pm 0.14$ & 5.18 & 3.15 & 1.48 & 0.47 \\
\hline $\mathrm{MnO}$ & $0.40 \pm 0.05$ & $0.49 \pm 0.10$ & b.d. & b.d. & 0.47 & 0.47 & 0.31 & b.d. \\
\hline $\mathrm{MgO}$ & $54.3 \pm 0.57$ & $37.8 \pm 9.72$ & $18.3 \pm 0.53$ & b.d. & 50.74 & 34.37 & 18.12 & 0.05 \\
\hline $\mathrm{CaO}$ & $0.02 \pm 0.01$ & $0.72 \pm 0.45$ & $22.5 \pm 0.56$ & $3.39 \pm 0.12$ & 0.03 & 1.59 & 20.69 & 4.26 \\
\hline $\mathrm{Na}_{2} \mathrm{O}$ & b.d. & $0.02 \pm 0.03$ & $0.57 \pm 0.05$ & $8.86 \pm 0.30$ & b.d. & b.d. & 0.61 & 8.19 \\
\hline $\mathrm{K}_{2} \mathrm{O}$ & b.d. & b.d. & b.d. & $0.68 \pm 0.10$ & b.d. & b.d. & b.d. & 0.67 \\
\hline Total & 100.4 & 99.19 & 99.8 & 100.4 & 98.65 & 98.49 & 101.3 & 99.09 \\
\hline Fo/En & 97.3 & 94.6 & 52.1 & & 5.4 & 92.3 & 53.6 & \\
\hline $\mathrm{Fa} / \mathrm{Fs}$ & 2.7 & 4.0 & 1.9 & & & 4.7 & 2.4 & \\
\hline An & & & & 16.8 & & & & 21.5 \\
\hline$A b$ & & & & 79.2 & & & & 74.6 \\
\hline \multirow[t]{3}{*}{ No. } & 17 & 14 & 17 & 22 & 10 & 10 & 8 & 3 \\
\hline & \multicolumn{4}{|l|}{ NWA 4024} & \multicolumn{4}{|l|}{ SAH 02029} \\
\hline & Ol & Opx & $C p x$ & PI & Ol & Opx & $C p x$ & PI \\
\hline $\mathrm{SiO}_{2}$ & $41.1 \pm 1.13$ & $58.3 \pm 1.01$ & $54.6 \pm 1.57$ & $67.5 \pm 3.48$ & $42.1 \pm 0.36$ & $58.3 \pm 0.74$ & $54.8 \pm 0.86$ & $55.2 \pm 0.85$ \\
\hline $\mathrm{TiO}_{2}$ & b.d. & $0.34 \pm 0.27$ & $0.60 \pm 0.15$ & $0.04 \pm 0.07$ & b.d. & $0.20 \pm 0.08$ & $0.48 \pm 0.10$ & $0.03 \pm 0.04$ \\
\hline $\mathrm{Al}_{2} \mathrm{O}_{3}$ & b.d. & $0.13 \pm 0.17$ & $0.62 \pm 0.11$ & $20.5 \pm 2.94$ & $0.03 \pm 0.04$ & $0.64 \pm 0.09$ & $1.25 \pm 0.13$ & $27.8 \pm 0.45$ \\
\hline $\mathrm{Cr}_{2} \mathrm{O}_{3}$ & b.d. & $0.07 \pm 0.12$ & $0.59 \pm 0.32$ & b.d. & $0.30 \pm 0.03$ & $0.48 \pm 0.08$ & $0.39 \pm 0.10$ & b.d. \\
\hline $\mathrm{FeO}$ & $4.33 \pm 0.16$ & $4.58 \pm 0.71$ & $1.76 \pm 0.26$ & $0.55 \pm 1.29$ & $2.78 \pm 0.16$ & $1.82 \pm 0.15$ & $1.15 \pm 0.82$ & $0.23 \pm 0.25$ \\
\hline $\mathrm{MnO}$ & $0.18 \pm 0.06$ & $0.18 \pm 0.07$ & b.d. & $0.06 \pm 0.19$ & $0.29 \pm 0.05$ & $0.31 \pm 0.03$ & b.d. & b.d. \\
\hline $\mathrm{MgO}$ & $53.9 \pm 1.23$ & $35.3 \pm 1.66$ & $18.2 \pm 0.46$ & b.d. & $54.0 \pm 0.75$ & $35.7 \pm 0.48$ & $19.9 \pm 0.32$ & $0.20 \pm 0.04$ \\
\hline $\mathrm{CaO}$ & $0.02 \pm 0.02$ & $0.85 \pm 0.30$ & $22.5 \pm 0.62$ & $1.05 \pm 1.91$ & $0.23 \pm 0.05$ & $2.21 \pm 0.07$ & $20.9 \pm 0.38$ & $10.3 \pm 0.33$ \\
\hline $\mathrm{Na}_{2} \mathrm{O}$ & b.d. & $0.02 \pm 0.03$ & $0.61 \pm 0.12$ & $10.25 \pm 1.4$ & $0.02 \pm 0.02$ & $0.05 \pm 0.06$ & $0.30 \pm 0.05$ & $5.24 \pm 0.18$ \\
\hline
\end{tabular}


Table 2 (continued)

\begin{tabular}{|c|c|c|c|c|c|c|c|c|}
\hline & NWA & & & & SAH 0 & & & \\
\hline & OI & Opx & Cpx & PI & OI & Opx & Cpx & PI \\
\hline $\mathrm{K}_{2} \mathrm{O}$ & b.d. & b.d. & b.d. & $0.85 \pm 0.66$ & b.d. & b.d. & b.d. & $0.02 \pm 0.03$ \\
\hline Total & 99.61 & 99.85 & 99.5 & 100.8 & 99.75 & 99.67 & 99.20 & 99.10 \\
\hline Fo/En & 95.7 & 91.7 & 51.4 & & 97.2 & 93.2 & 56.0 & \\
\hline $\mathrm{Fa} / \mathrm{Fs}$ & 4.3 & 6.7 & 2.8 & & 2.8 & 2.7 & 1.8 & \\
\hline An & & & & 5.1 & & & & 52.0 \\
\hline$A b$ & & & & 90.0 & & & & 47.8 \\
\hline No. & 7 & 9 & 6 & 8 & 7 & 7 & 14 & 11 \\
\hline
\end{tabular}

Fo $=$ atomic $100 \times \mathrm{Mg} /[\mathrm{Fe}+\mathrm{Mg}], \mathrm{En}=$ atomic $100 \times \mathrm{Mg} /[\mathrm{Mg}+\mathrm{Fe}+\mathrm{Ca}], \mathrm{Fa}=$ atomic $100 \times \mathrm{Fe} /[\mathrm{Fe}+\mathrm{Mg}], \mathrm{Fs}=\mathrm{atomic} 100 \times \mathrm{Fe} /[\mathrm{Mg}+\mathrm{Fe}+\mathrm{Ca}], \mathrm{An}=\mathrm{atomic} 100 \times \mathrm{Ca} /$ $[\mathrm{Ca}+\mathrm{Na}+\mathrm{K}], \mathrm{Ab}=$ atomic $100 \times \mathrm{Na} /[\mathrm{Ca}+\mathrm{Na}+\mathrm{K}]$

Error for the analyzed elements are 2-sigma standard deviation (2 SD)

b.d.= below detection limit

No. $=$ number of analyses

a Data were taken from Li et al. (2011)
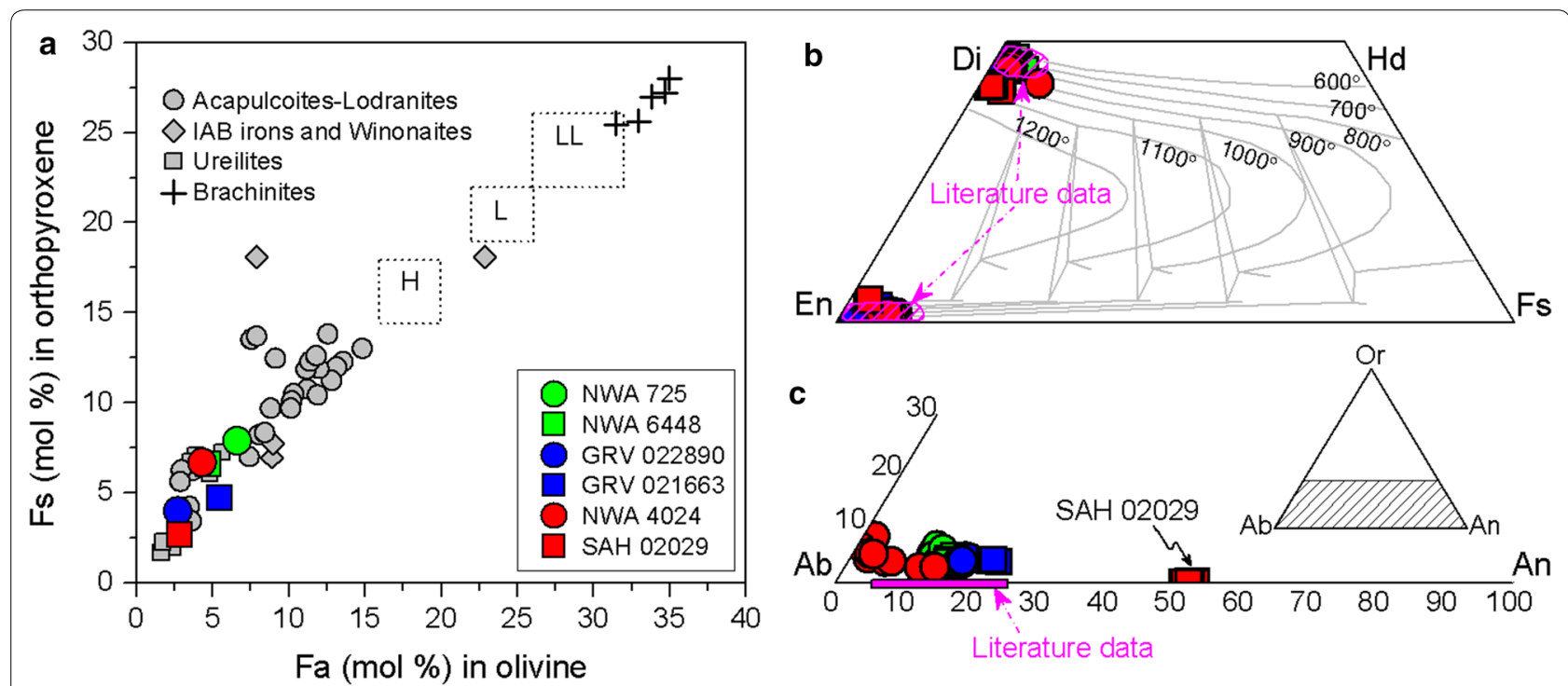

Fig. 5 Mineral composition of silicate phases in winonaites. a Fa versus Fs (mol \%) in olivine and orthopyroxene, respectively (modified from Folco et al. 2006); composition of pyroxene (b) and plagioclase (c) in the studied meteorites (the literature data were taken from Goodrich et al. 2011). The two-pyroxene thermometer boundaries were taken from Lindsley and Andersen (1983)

et al. (2008). However, the clinopyroxenes in SAH 02029 obviously display distinctive REE abundance and pattern; this meteorite shows relatively low abundance of $\mathrm{REE}(\mathrm{La} \sim 1 \times \mathrm{CI}, \mathrm{Lu} \sim 6 \times \mathrm{CI})$ and exhibits light rare earth element (LREE)-depleted pattern, compared with other winonaites (Fig. 6b).

In our study, plagioclase grains in most analyzed winonaites show a large variation of REE abundances (e.g., La varies from $\sim 1$ to $\sim 7 \times \mathrm{CI}$ ) and display a typical LREEenriched pattern (Fig. 6c) with positive Eu-anomalies $(\sim 10-20 \times C I)$. These results are similar to those of other reported winonaites (Fig. 6c; Floss et al. 2008). However, the studied SAH 02029 contains a relatively high abundance of HREE than that in other winonaites, showing approximately flat REE pattern (Fig. 6c).

\section{Discussion}

Textural and mineralogical diversity among winonaites

The studied winonaites exhibit a diverse texture and mineralogy that are similar to other reported winonaites. NWA 725 contains small amount $(\sim 5 \mathrm{vol} \%)$ of relic chondrules, exhibiting similar texture with those of NWA 

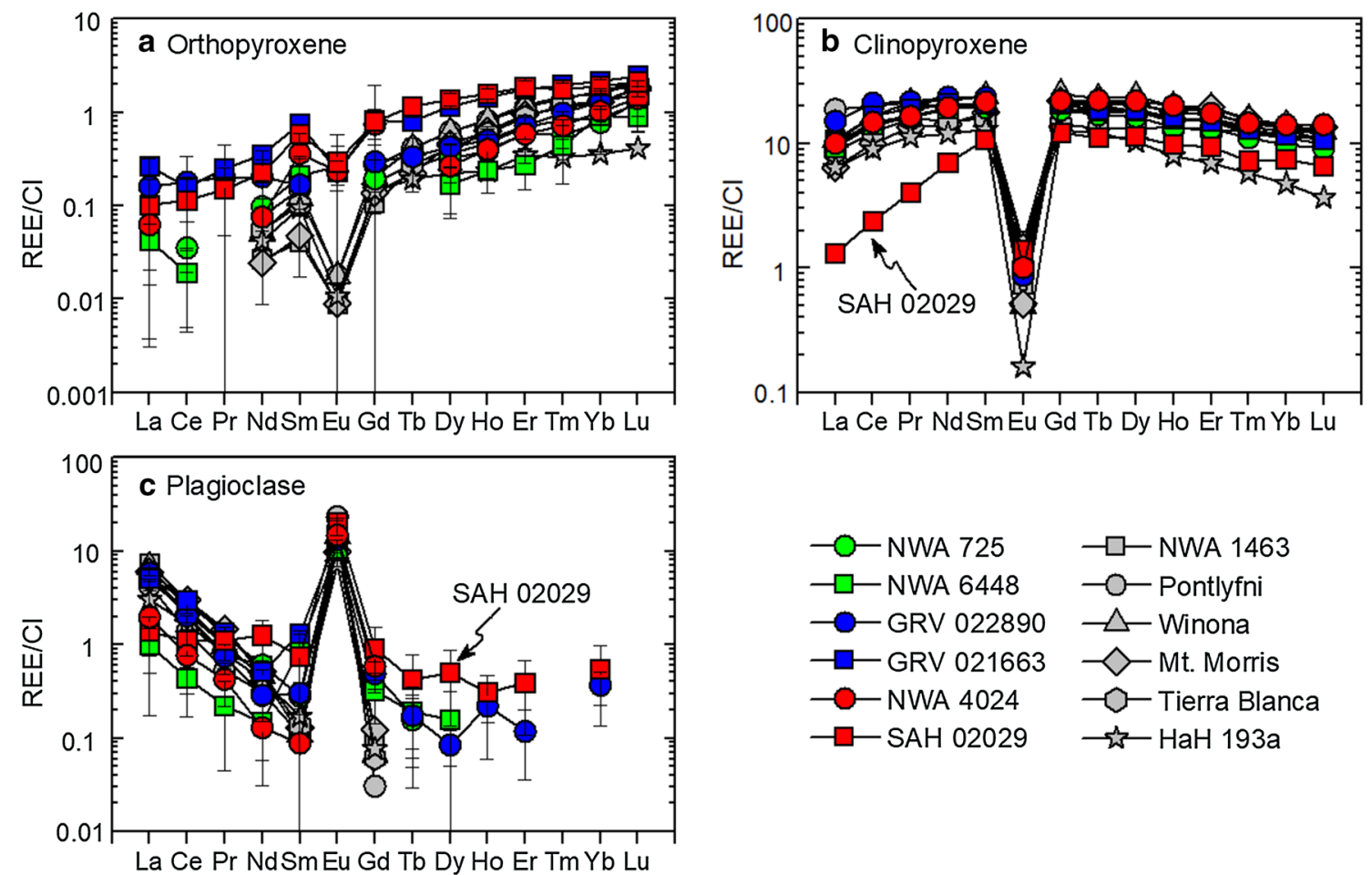

Fig. 6 Average Cl chondrite-normalized (Anders and Grevesse 1989) REE patterns for orthopyroxene (a), clinopyroxene (b), and plagioclase (c) in winonaites. The color symbols represent the studied meteorites. The light gray symbols represent the literature data for other winonaites (Floss et al. 2008). REE composition for GRV 021663 was taken from Li et al. (2011). Error bars (1 SD) are shown for orthopyroxene and plagioclase. The error bars (1 SD) for clinopyroxene are within the size of the symbol

1463 and NWA 8614 that are thought to be the primitive materials of winonaite parent body (e.g., Benedix et al. 1998; Floss et al. 2008; Farley et al. 2015). The GRV 022890, which exhibits recrystallized texture (Fig. 2f), is similar to the plagioclase-clinopyroxene-rich regions in Pontlyfni (e.g., Figure 2a of Floss et al. 2008). In addition, the coarse-grained olivine-rich winonaite GRV 021663 shares similar petrologic textures with the coarse-grained olivine lithologies found in Winona and Mount Morris (Benedix et al. 1998; Floss et al. 2008). Furthermore, our new data (Fig. 4 and Table 1 ) also extend the variation of modal mineralogy of winonaites. For example, (1) NWA 6448 has the largest abundant of orthopyroxene (53.8 vol\%) among the winonaites; (2) GRV 021663 contains the most abundant of olivine of $49.5 \mathrm{vol} \%$ and the least amount of plagioclase of $1.7 \mathrm{vol} \%$; and (3) NWA 4024 is a FeNi metal-rich $(80.5$ vol\%) winonaite.

\section{SAH 02029: an unusual winonaite achondrite}

Similarities in oxygen isotopic compositions and mineralogy of SAH 02029 and winonaite achondrites suggest that SAH 02029 is a member of winonaite group (Russell et al. 2004; Greenwood et al. 2012). Texturally, SAH 02029 is similar to the reported coarse-grained winonaite Tierra
Blanca (e.g., Benedix et al. 1998). Both of them have an equigranular texture with abundant $120^{\circ}$ triple junctions (see Fig. 3a here and Fig. $2 \mathrm{~g}$ of Benedix et al. 1998), and both also display clumps of olivine grains (Fig. If and Fig. 7 of Benedix et al. 1998). Using two-pyroxene thermometer (Lindsley and Andersen 1983), SAH 02029 has relatively high two-pyroxene equilibration temperature of $\sim 1100$ (Fig. $5 \mathrm{~b}$ ), which is similar to the equilibration temperature for Tierra Blanca $\left(\sim 1100-1200{ }^{\circ} \mathrm{C}\right.$; Benedix et al. 1998; Yugami et al. 1999) within the uncertainties (i.e., $100{ }^{\circ} \mathrm{C}$; Benedix et al. 1998).

Despite the textural similarities to Tierra Blanca, our study shows that SAH 02029 exhibits unusual mineralogy and mineral composition among the winonaite group. These differences include the following: (1) Tierra Blanca contains large (up to $9 \mathrm{~mm}$ in size) crystals of clinopyroxene, which poikilitically enclose silicate grains (i.e., olivine, orthopyroxene, and plagioclase), and shows no preferential association with plagioclase (King et al. 1981; Benedix et al. 1998; Floss et al. 2008). However, the clinopyroxene grains in the studied SAH 02029 are isolated small grains (less than $\sim 800 \mu \mathrm{m}$ in size) and frequently associated with the plagioclase grains (e.g., Fig. 3a). (2) SAH 02029 contains relatively low abundance of troilite 
of 2.3 vol\%, compared with other reported winonaites which have high troilite content (i.e., 3.5-13.5 vol\%; NWA 4024 is an exception as it contains much abundant of FeNi metal; see Fig. 4). (3) The melt inclusions were observed in plagioclase of SAH 02029 (Fig. 3c, d), while other winonaites not. (4) Plagioclase compositions in most winonaites are relatively Na-rich (i.e., $A n=\sim 5-26$; Fig. 5c), while the plagioclase in SAH 02029 is Ca-rich (i.e., $\mathrm{An}=52.0$ ). (5) Clinopyroxenes in SAH 02029 are relatively depleted in REE abundance and shows significant LREE depletion, while other winonaites contain the clinopyroxenes showing approximately flat patterns (Fig. 6b). (6) Compared with other winonaites, the plagioclase grains in SAH 02029 show distinct REE pattern (i.e., approximately flat pattern) and contain relatively high abundance of HREE (Fig. 6c).

\section{The partial melting recorded by SAH 02029}

Petrologic texture and mineral chemistry suggest that SAH 02029 has undergone silicate partial melting and may represent the residue of partial melting from winonaite-IAB parent body. The evidence includes the following: (1) Silicate partial melting in a chondritic system is thought to begin at temperature of $\sim 1100{ }^{\circ} \mathrm{C}$ (e.g., Ford et al. 2008). Such temperature is consistent with the calculated two-pyroxene peak temperatures of SAH 02029 (i.e., $1100{ }^{\circ} \mathrm{C}$; Fig. 5b). (2) Most clinopyroxene grains in SAH 02029 are associated with plagioclase (Fig. 3a), which is commonly expected from crystallization of a basaltic partial melt (e.g., McCoy et al. 1997a, b; Mittlefehldt et al. 1996; Benedix et al. 1998). (3) The fine-grained mafic silicates (e.g., olivine) were poikilitically enclosed by plagioclase (e.g., Fig. 3a). Such texture is consistent with the silicate partial melting texture observed in lodranites (McCoy et al. 1997a, b) and the partially melted H7 ordinary chondrite Watson 012 (Tait et al. 2014) as well as the LL7 ordinary chondrite Yamato 74160 (Takeda et al. 1984). (4) Melt inclusions were observed in the plagioclase grains of SAH 02029 (e.g., Fig. 3c, d), suggesting that silicate partial melting has occurred. A similar texture is also observed in the QUE 94204 enstatite, which has been interpreted as the product of partial melting of an enstatite chondrite-like material (e.g., Figures 2D-F of Izawa et al. 2011). (5) SAH 02029 has clinopyroxenes characterized by a LREE-depleted pattern with negative Eu-anomaly (Fig. 6b), which is expected in the partial melting residue (e.g., Floss 2000). Compared with the acapulcoite-lodranite clan, SAH 02029 shows similar pyroxene REE pattern with the lodranite MAC 88177, which also exhibits clinopyroxene LREE depletion (Floss 2000). (6) The plagioclase in SAH 02029 contains relatively high abundance of HREE and shows an approximately CI-normalized flat pattern, while other analyzed winonaites are characterized by lower abundances of HREE in plagioclase (Fig. 6c). The high abundance HREE of plagioclase from SAH 02029 is probably due to the in situ recrystallization or interaction of plagioclase grains with a melt with approximately flat pattern (probable through phosphate melting; Floss 2000; Floss et al. 2008).

The occurrence of troilite and plagioclase in the section of SAH 02029 suggests that the cotectic FeNi-FeS and basaltic partial melts were not efficiently extracted from its source region. Compared with most winonaites that have average troilite and plagioclase contents of $7.6 \mathrm{vol} \%$ and $\sim 10.5 \mathrm{vol} \%$, respectively (Fig. 4 and Table 1), SAH 02029 exhibits relative depletion of troilite $(2.3 \mathrm{vol} \%)$ and plagioclase $(6.4 \mathrm{vol} \%)$. The reduced part of troilite and plagioclase partial melt has most likely been removed (e.g., Keil and Bischoff 2008; Izawa et al. 2011). We, therefore, estimate that the degree of partial melting for SAH 02029 is $~ 5-10$ vol\%. By analogy with the observations of acapulcoite-lodranite meteorites, once $\sim 5-10 \mathrm{vol} \%$ of partial melting has taken place, the residue would be relatively depleted in troilite and plagioclase (e.g., the lodranite LEW 88280 and FRO 90011; McCoy et al. 1997a, b). Such characteristics are consistent with the petrological texture and mineralogy observed in SAH 02029.

\section{The layered structure model for winonaite-IAB parent asteroid}

Two major hypotheses for the origin of the winonaiteIAB meteorites has been proposed: impact-related heating and radiogenic heating (e.g., Wasson and Kallemeyn 2002; Benedix et al. 2000). For impact heating, melting and metamorphism may have taken place in a shallow region of the parent body (e.g., Keil et al. 1997; Tait et al. 2014). It is difficult to produce enough heat via this process for the incipient partial melting on winonaite parent body. Also, the chondritic or equigranular textures of winonaites are inconsistent with the impact heating model, as such a process would likely form rocks with igneous textures (e.g., Ruzicka et al. 2019). In the case of radiogenic heating (e.g., by heat from ${ }^{26} \mathrm{Al}$ ), the temperature gets higher as the depth increases within the parent body. This model has been generally accepted as being responsible for the incomplete differentiation of winonaite-IAB parent body (Benedix et al. 2000; Theis et al. 2013; Hunt et al. 2017, 2018).

The heterogeneous lithologies of winonaites and IAB silicate inclusions suggest that the incompletely differentiated winonaite-IAB parent asteroid was later shaped by a catastrophic impact breakup and reassembly (Benedix et al. 2000; Hunt et al. 2017). This is in agreement with the brecciated nature of metal-rich NWA 4024, which was mixed by two different lithologies (i.e., winonaite silicates 
and IAB meteorite-like metals; Fig. 1e). The catastrophic impact would further halt the differentiation process on winonaite-IAB parent asteroid, allowing the preservation of the diverse winonaites (Benedix et al. 2000; Hunt et al. 2017). In this scenario, the textural and mineralogical diversity of winonaites could record the thermal history and internal structure of winonaite-IAB parent asteroid before the catastrophic impact breakup event (e.g., Hunt et al. 2018). Specifically, the winonaite indicating higher temperature comes from the deeper part, while the lithologies with low thermal metamorphism originate from the outer layers (Hunt et al. 2017).

By analogy with other meteorite groups such as the acapulcoites-lodranites and $\mathrm{H}$-chondrites, which also exhibit diverse lithologies and were suggested to have a multilayered parent body (e.g., McCoy et al. 1996; Benedix et al. 2000; Trieloff et al. 2003; Eugster and Lorenzetti 2005; Li et al. 2018), our study and previous investigations (e.g., Benedix et al. 2000) suggest that a four-layered structure is most likely to be formed through incomplete differentiation on winonaite-IAB parent asteroid (Fig. 7). Based on the available petrological and mineralogical data of winonaites, the layered structure model for winonaite-IAB parent asteroid is discussed below:

1. Surface layer consisting of chondritic materials

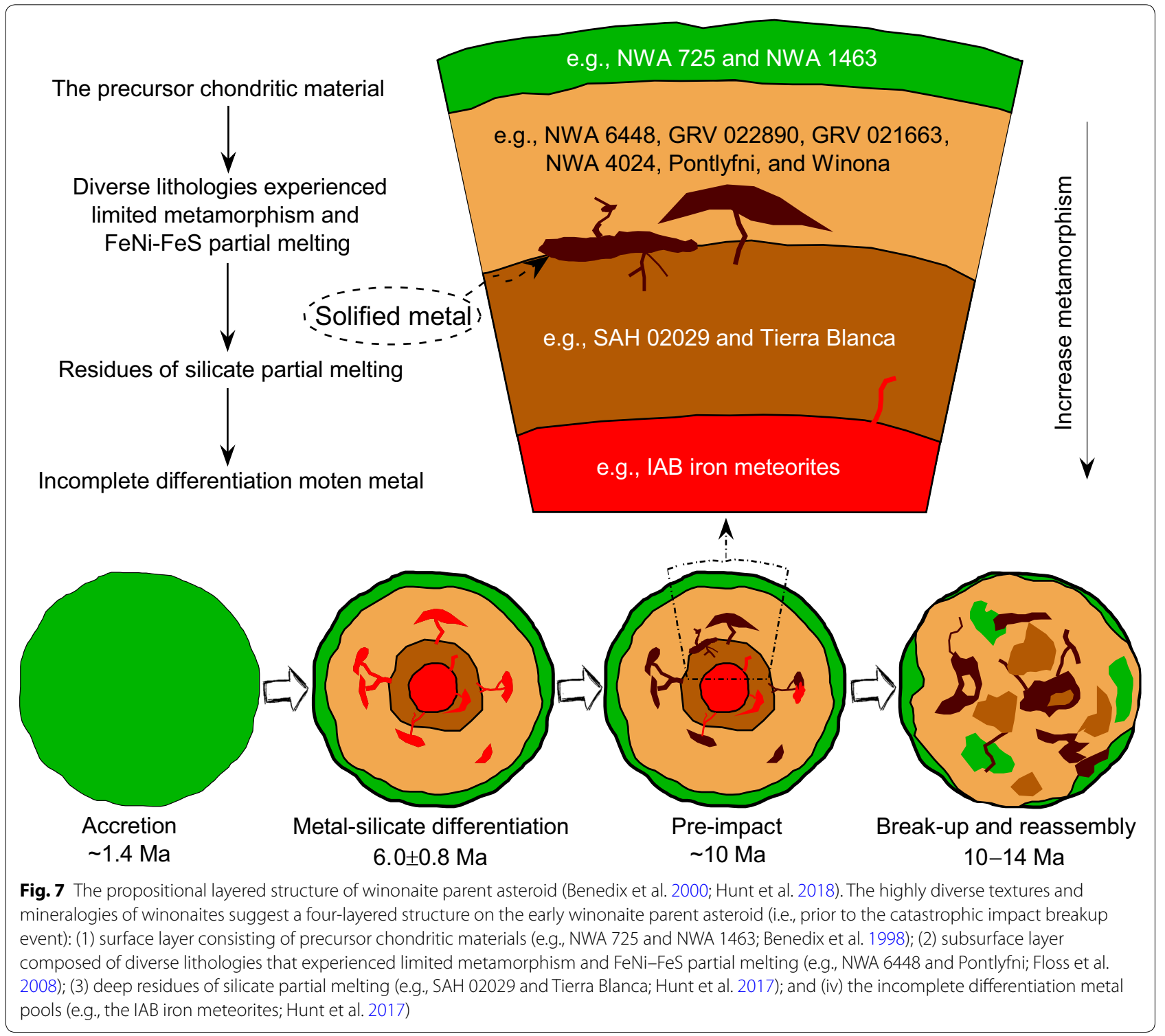


The winonaites with chondritic textures (e.g., NWA 725, NWA 1463, and NWA 8614) are believed to represent the most primitive winonaite samples and, thus, the precursor materials from which this meteorite group originated (Benedix et al. 2003; Floss et al. 2008; Farley et al. 2015). They contain relic chondrules and share similar petrologic texture with type 5 or 6 ordinary chondrites, suggesting that they experienced a metamorphic temperature of $\sim 800{ }^{\circ} \mathrm{C}$, less than the metamorphism temperature for most winonaites (i.e., $900-1200{ }^{\circ} \mathrm{C}$; Benedix et al. 1998; Kovach and Jones 2010). Such relatively low metamorphism temperature suggests that the winonaites with chondritic texture most likely originate from the surface layer of their parent body, rather than the interior. This conclusion is consistent with the modeling result that a primordial chondritic shell can survive in the upper layers of a planetesimal (Lichtenberg et al. 2016). Also, the relatively large porosity (e.g., 10\% for NWA 725) for these winonaites with chondritic texture (Fig. 2c; Fig. 1 of Farley et al. 2015) indicates that this chondritic material is not likely to be derived from the interior of a winonaite-IAB parent asteroid.

2. Subsurface layer composed of diverse lithologies that experienced limited metamorphism and partial melting

Most winonaites (e.g., NWA 6448, GRV 022890, GRV 021663, Pontlyfni, and Winona; Benedix et al. 1998; Floss et al. 2008; this study) have a mixture of fine-, medium-, and coarse-grained equigranular texture. These samples reached a peak temperature of $<1200{ }^{\circ} \mathrm{C}$ and experienced limited metamorphism, resulting in limited partial melting (Benedix et al. 1998, 2005; Floss et al. 2007, 2008; Hunt et al. 2017; Li et al. 2018). By comparing to the primitive achondrite group of acapulcoite-lodranite clans, these diverse winonaite lithologies share similar petrology and mineralogy (e.g., recrystallization texture, $\mathrm{FeNi}-\mathrm{FeS}$ partial melting, and approximately chondritic mineralogy) with the acapulcoite meteorites which were thought to represent the outer layer of their parent body (Eugster and Lorenzetti 2005). Thus, it is reasonable to infer that the subsurface of winonaite-IAB parent body is mainly composed of the diverse winonaites that experienced limited metamorphism and $\mathrm{FeNi}-\mathrm{FeS}$ partial melting.

\section{Deep residue of partial melting}

In this study, textural and mineralogical evidence suggests that SAH 02029 could represent a residue left behind after $\sim 5-10$ vol\% partial melting. The coarsegrained Tierra Blanca meteorite is also recognized as residue of small-degree silicate melting from geochemical evidence (Hunt et al. 2017). In addition, some silicate inclusions in IAB iron meteorites (e.g., Udei Station) contain the lithologies that formed as the residue of partial melting (Benedix et al. 2000; Takeda et al. 2000; Ruzicka and Hutson 2010). By analogy with the observations for acapulcoite-lodranite meteorites, the SAH 02029 and other partial melt residues are more similar to the lodranite meteorites that are thought to represent the partial melting residue from the deep region of acapulcoite-lodranite parent body (McCoy et al. 1997a; Eugster and Lorenzetti 2005; Li et al. 2018). These residues of silicate melting (e.g., SAH 02029 and Tierra Blanca) most likely represent the deep lithologies on winonaite-IAB parent asteroid.

To date, only a few lithologies have been recognized as residue of high degree (i.e., $>20 \%$ ) of partial melting from winonaite-IAB parent body (Benedix et al. 1998, 2000; Hunt et al. 2017). Our study implies that a limited partial melting and fractionation has occurred on winonaite-IAB parent asteroid. For the studied SAH 02029, it is lithologically different from other reported partial melt residues, because this meteorite shows unusual petrologic textures (e.g., melt inclusions in plagioclase) and mineral chemistry (e.g., Ca-rich plagioclase and clinopyroxene depleted in LREE) (Figs. 3a-d, 5c, and 6b; Benedix et al. 1998, 2000). This indicates that the deep lithologies on winonaite-IAB parent asteroid are likely more mineralogically diverse than previously thought.

\section{Interior layer consisting of incomplete differentiation metal pools}

The abundant $I A B$ irons suggest that winonaite$\mathrm{IAB}$ parent asteroid began to differentiate and form at least one metallic body before the catastrophic impact breakup event (Benedix et al. 2000; Hunt et al. 2017). Both the chondritic mineralogy and geochemical data of winonaites suggest that this differentiation process did not complete (Benedix et al. 1998; Floss et al. 2008; Hunt et al. 2017). If this scenario is correct, we suggested that the interior of early winonaite-IAB parent asteroid is most likely composed of the incomplete differentiation metal pools.

\section{Conclusions}

The six studied winonaites exhibit a diversity of petrographic textures, including chondritic texture (i.e., NWA 725), fine-grained texture (i.e., NWA 6448), recrystallized texture (i.e., GRV 022890), olivine-rich texture (i.e., GRV 021663), metal-rich texture (i.e., NWA 4024), and coarse-grained troilite-poor texture (i.e., SAH 02029). In particular, an unusual winonaite, SAH 02029, has been 
recognized. This sample shows distinctive mineralogy and mineral chemistry (e.g., depleted in troilite, high plagioclase An values, and clinopyroxene depleted in LREE) compared with other winonaites. Textural and mineralogical features suggest that SAH 02029 most likely represents a residue of $\sim 5-10 \mathrm{vol} \%$ partial melting.

The textural and mineralogical diversity among winonaite group implies that a four-layered structure could be formed during the evolution history of winonaite-IAB parent asteroid: (1) surface layer consisting of chondritic materials; (2) subsurface layer composed of diverse lithologies that experienced limited metamorphism and partial melting; (3) deep residues of silicate partial melting; and (4) interior layer consisting of incomplete differentiation metal pools. In the future, investigation of more winonaite samples would be helpful to demonstrate this layered structure model. Also, other geochemical and chronological works (e.g., the highly siderophile elements and ${ }^{39} \mathrm{Ar}-{ }^{40} \mathrm{Ar}$ age for different lithologies) could be carried out, to better understand the structure and evolution history of winonaite-IAB parent asteroid.

\section{Additional file}

Additional file 1. Additional figures showing the six studied winonaite sections (Figure $\mathrm{A} 1$ ) and the elemental composite maps of these meteorites (Figure A2-7). The rare earh elements composition for orthopyroxene, clinopyroxene, and plagioclase was provided in Table A1.

\section{Abbreviations}

NWA: Northwest Africa; GRV: Grove Mountains; SAH: Sahara; REE: rare earth element; LREE and HREE: light and heavy rare earth element.

\section{Authors' contributions}

SL and SW conceived this research. XZ and YS performed the research. XZ prepared the paper draft. All authors participated in the discussion of results and contributed to the editing of the final manuscript. All authors read and approved the final manuscript.

\section{Author details}

${ }^{1}$ Center for Lunar and Planetary Sciences, Institute of Geochemistry, Chinese Academy of Sciences, Guiyang 550081, China. ${ }^{2}$ CAS Center for Excellence in Comparative Planetology, Hefei, China. ${ }^{3}$ Key Laboratory of Space Manufacturing Technology, Chinese Academy of Sciences, Beijing 100094, China. ${ }^{4}$ University of Chinese Academy of Sciences, Beijing 100049, China. ${ }^{5}$ State Key Laboratory of Environmental Geochemistry, Institute of Geochemistry, Chinese Academy of Sciences, Guiyang 550081, China.

\section{Acknowledgements}

The sections of GRV 022890 and GRV 021663 were provided by the Polar Research Institute of China (PRIC). We thank Dr. Takaaki Noguchi for the editorial handling, and Dr. Gretchen Benedix and two anonymous reviewers for their constructive comments. X. Zeng would like to thank Dr. Gretchen Benedix for her helpful suggestions on an earlier version of this manuscript and Dr. Katherine Joy (University of Manchester) for editing the manuscript. The authors also thank Rui Li, Zhihui Dai, and Yizhi Liu for assistance with SEM, LA-ICPMS, and EMP techniques, respectively.

\section{Competing interests}

The authors declare that they have no competing interests.

\section{Availability of data and materials}

The data and materials are available upon request from the first author Xiaojia Zeng (e-mail:zengxiaojia@mail.gyig.ac.cn).

\section{Funding}

This research was supported by the National Natural Science Foundation of China (Grant Nos. 41273080, 41473067, and 41490630).

\section{Publisher's Note}

Springer Nature remains neutral with regard to jurisdictional claims in published maps and institutional affiliations.

Received: 15 October 2018 Accepted: 18 March 2019

Published online: 02 April 2019

\section{References}

Anders E, Grevesse N (1989) Abundances of the elements: meteoritic and solar. Geochim Cosmochim Acta 53:197-214

Benedix GK, McCoy TJ, Keil K, Bogard DD, Garrison DH (1998) A petrologic and isotopic study of winonaites: evidence for early partial melting, brecciation, and metamorphism. Geochim Cosmochim Acta 62:2535-2553

Benedix GK, McCoy TJ, Keil K, Love SG (2000) A petrologic study of the IAB iron meteorites: constraints on the formation of the IAB-winonaite parent body. Meteorit Planet Sci 35:1127-1141

Benedix GK, McCoy TJ, Lauretta DS (2003) Is NWA 1463 the most primitive winonaite? Meteorit Planet Sci Suppl 38:5125 (abstr.)

Benedix GK, Lauretta DS, McCoy TJ (2005) Thermodynamic constraints on the formation conditions of winonaites and silicate-bearing IAB irons. Geochim Cosmochim Acta 69:5123-5131

Cecchi V, Caporali S (2015) Petrologic and minerochemical trends of acapulcoites, winonaites and lodranites: new evidence from image analysis and EMPA investigations. Geosciences 5:222-242

Clayton RN, Mayeda TK (1996) Oxygen isotope studies of achondrites. Geochim Cosmochim Acta 60:1999-2017

Eugster O, Lorenzetti S (2005) Cosmic-ray exposure ages of four acapulcoites and two differentiated achondrites and evidence for a two-layer structure of the acapulcoite/lodranite parent asteroid. Geochim Cosmochim Acta 69:2675-2685

Farley KR, Ruzicka AM, Armstrong K (2015) Nwa 8614: the least heated winonaite? In: Lunar andPlanetary Science Conference, vol 46, p 1821

Floss C (2000) Complexities on the acapulcoite-lodranite parent body: evidence from trace element distributions in silicate minerals. Meteorit Planet Sci 35:1073-1085

Floss C, Jolliff B, Benedix G, Stadermann F, Reid J (2007) Hammadah al hamra 193: the first amphibole-bearing winonaite. Am Mineral 92:460-467

Floss C, Crozaz G, Jolliff B, Benedix G, Colton S (2008) Evolution of the winonaite parent body: clues from silicate mineral trace element distributions. Meteorit Planet Sci 43:657-674

Folco L, D'Orazio M, Burroni A (2006) Frontier mountain 93001: a coarsegrained, enstatite-augite-oligoclase-rich, igneous rock from the acapulcoite-lodranite parent asteroid. Meteorit Planet Sci 41:1183-1198

Ford RL, Benedix GK, McCoy TJ, Rushmer T (2008) Partial melting of H6 ordinary chondrite Kernouvé: constraints on the effects of reducing conditions on oxidized compositions. Meteorit Planet Sci 43:1399-1414

Goodrich CA, Kita NT, Spicuzza MJ, Valley JW, Zipfel J, Mikouchi T et al (2011) The Northwest Africa 1500 meteorite: not a ureilite, maybe a brachinite. Meteorit Planet Sci 45:1906-1928

Graham AL, Easton A, Hutchison R (1977) Forsterite chondrites; the meteorites Kakangari, Mount Morris (Wisconsin), Pontlyfni, and Winona. Mineral Mag 41:201-210

Greenwood RC, Franchi IA, Gibson JM, Benedix GK (2012) Oxygen isotope variation in primitive achondrites: the influence of primordial, asteroidal and terrestrial processes. Geochim Cosmochim Acta 94:146-163

Grossman JN, Zipfel J (2001) The meteoritical bulletin, no. 85, 2001 september. Meteorit Planet Sci 36:A293-A322

Hunt AC, Benedix GK, Hammond SJ, Bland PA, Rehkämper M, Kreissig K et al (2017) A geochemical study of the winonaites: evidence for limited 
partial melting and constraints on the precursor composition. Geochim Cosmochim Acta 199:13-30

Hunt AC, Cook DL, Lichtenberg T, Reger PM, Ek M, Golabek GJ et al (2018) Late metal-silicate separation on the IAB parent asteroid: constraints from combined $\mathrm{W}$ and Pt isotopes and thermal modelling. Earth Planet Sci Lett 482:490-500

Izawa MRM, Flemming RL, Banerjee NR, Matveev S (2011) Que 94204: a primitive enstatite achondrite produced by the partial melting of an e chondrite-like protolith. Meteorit Planet Sci 46:1742-1753

Keil K, Bischoff A (2008) Northwest africa 2526: a partial melt residue of enstatite chondrite parentage. Meteorit Planet Sci 43:1233-1240

Keil K, Stoeffler D, Love SG, Scott ERD (1997) Constraints on the role of impact heating and melting in asteroids. Meteorit Planet Sci 32:349-363

Kimura M, Tsuchiyama A (1992) Antarctic primitive achondrites Yamato-74025, -75300 , and -75305 : their mineralogy, thermal history and the relevance to winonaite. In: Nipr symposium on antarctic meteorites. National Institute of Polar Research, vol 5, pp 165-190

King EA, Jarosewich E, Daugherty FW (1981) Tierra Blanca: an unusual achondrite from West Texas. Meteorit Planet Sci 16:229-237

Kovach HA, Jones RH (2010) Feldspar in type 4-6 ordinary chondrites: metamorphic processing on the $\mathrm{h}$ and II chondrite parent bodies. Meteorit Planet Sci 45:246-264

Lee MR, Bland PA (2004) Mechanisms of weathering of meteorites recovered from hot and cold deserts and the formation of phyllosilicates. Geochim Cosmochim Acta 68:893-916

Li S, Wang S, Bao H, Miao B, Liu S, Coulson IM, Li X, Li Y (2011) The Antarctic achondrite, Grove Mountains 021663: an olivine-rich winonaite. Meteorit Planet Sci 46:1329-1344

Li S, Yin QZ, Bao H, Sanborn ME, Irving A, Ziegler K, Agee C, Marti K, Miao B, Li $X$, Li Y, Wang S (2018) Evidence for a multilayered internal structure of the chondritic acapulcoite-lodranite parent asteroid. Geochim Cosmochim Acta. https://doi.org/10.1016/j.gca.2018.09.004 (in press)

Lichtenberg T, Golabek GJ, Gerya TV, Meyer MR (2016) The effects of shortlived radionuclides and porosity on the early thermo-mechanical evolution of planetesimals. Icarus 274:350-365

Lindsley DH, Andersen DJ (1983) A two-pyroxene thermometer. J Geophys Res Solid Earth 88:A887-A906

Liu Y, Hu Z, Gao S, Günther D, Xu J, Gao C et al (2008) In situ, analysis of major and trace elements of anhydrous minerals by la-icp-ms without applying an internal standard. Chem Geol 257:34-43

Liu YS, Hu ZC, Zong KQ, Gao CG, Gao S, Xu J et al (2010) Reappraisement and refinement of zircon $\mathrm{u}$-pb isotope and trace element analyses by la-icpms. Sci Bull 55:1535-1546

Macke R, Britt D, Consolmagno G (2011) Density, porosity, and magnetic susceptibility of achondriticmeteorites. Meteorit Planet Sci 46:311-326

McCoy TJ, Keil K, Clayton RN, Mayeda TK, Bogard DD, Garrison DH et al (1996) A petrologic, chemical, and isotopic study of monument draw and comparison with other acapulcoites: evidence for formation by incipient partial melting. Geochim Cosmochim Acta 60:2681-2708

McCoy TJ, Keil K, Muenow DW, Wilson L (1997a) Partial melting and melt migration in the acapulcoite-lodranite parent body. Geochim Cosmochim Acta 61:639-650

McCoy TJ, Keil K, Clayton RN, Mayeda TK, Bogard DD, Garrison DH et al (1997b) A petrologic and isotopic study of lodranites: evidence for early formation as partial melt residues from heterogeneous precursors. Geochim Cosmochim Acta 61:623-637
Mittlefehldt DW, Lindstrom MM, Bogard DD, Garrison DH, Field SW (1996) Acapulco- and lodran-like achondrites: petrology, geochemistry, chronology, and origin. Geochim Cosmochim Acta 60:867-882

Prinz M, Waggoner DG, Hamilton PJ (1980) Winonaites: a primitive achondritic group related to silicate inclusions in IAB irons. In: Lunar and planetary science conference, vol 11, pp 902-904

Russell SS, Folco L, Grady MM, Zolensky M, Jones R, Righter K, Zipfel J, Grossman JN (2004) The meteoritical bulletin, no. 88, 2004 september. Meteorit Planet Sci 39:A215-A272

Ruzicka A, Hutson M (2010) Comparative petrology of silicates in the Udei Station (IAB) and Miles (IIE) iron meteorites: implications for the origin of silicate-bearing irons. Geochim Cosmochim Acta 74:394-433

Ruzicka AM, Greenwood RC, Armstrong K, Schepker KL, Franchi IA (2019) Petrology and oxygen isotopic composition of large igneous inclusions in ordinary chondrites: Early solar system igneous processes and oxygen reservoirs. Geochim Cosmochim Acta. https://doi.org/10.1016/j. gca.2019.01.017

Tait AW, Tomkins AG, Godel BM, Wilson SA, Hasalova P (2014) Investigation of the $\mathrm{h} 7$ ordinary chondrite, Watson 012 : implications for recognition and classification of type 7 meteorites. Geochim Cosmochim Acta 134:175-196

Takeda H, Huston TJ, Lipschutz ME (1984) On the chondrite-achondrite transition: mineralogy and chemistry of Yamato 74160 (LL7). Earth Planet Sci Lett 71:329-339

Takeda H, Bogard DD, Mittlefehldt DW, Garrison DH (2000) Mineralogy, petrology, chemistry, and 39Ar-40Ar and exposure ages of the Caddo County IAB iron: evidence for early partial melt segregation of a gabbro area rich in plagioclase-diopside. Geochim Cosmochim Acta 64:1311-1327

Theis KJ, Schönbächler M, Benedix GK, Rehkämper M, Andreasen R, Davies C (2013) Palladium-silver chronology of IAB iron meteorites. Earth Planet Sci Lett 361:402-411

Trieloff M, Jessberger EK, Herrwerth I, Hopp J, Fiéni C, Ghélis M et al (2003) Structure and thermal history of the $\mathrm{h}$-chondrite parent asteroid revealed by thermochronometry. Nature 422:502-506

Wasson JT, Kallemeyn GW (2002) The IAB iron-meteorite complex: a group, five subgroups, numerous grouplets, closely related, mainly formed by crystal segregation in rapidly cooling melts. Geochim Cosmochim Acta 66:2445-2473

Wlotzka F (1993) A weathering scale for the ordinary chondrites. Meteoritics 28:460

Worsham EA, Bermingham KR, Walker RJ (2017) Characterizing cosmochemical materials with genetic affinities to the earth: genetic and chronological diversity within the IAB iron meteorite complex. Earth Planet Sci Lett 467:157-166

Yugami K, Takeda H, Kojima H, Miyamoto M (1998) Modal abundances of minerals of primitive achondrites and the endmember mineral assemblage of the differentiation trend. Antarct Meteor Res 11:49-70

Yugami K, Takeda H, Kojima H, Miyamoto M (1999) Comparisons of textural and chemical variations of minerals in some primitive achondrites and an $\mathrm{H} 7$ chondrite, with reference to their formation and cooling histories. Antarct Meteor Res 12:117-138

Zeng X, Li S, Leya I, Wang S, Smith T, Li Y, Wang P (2018) The Kumtag 016 L5 strewn field, Xinjiang Province, China. Meteorit Planet Sci 53:1113-1130 